\title{
A Study on the Application of Successful Forest Greening Experience for Forest and Landscape Restoration: A Comparative Study of Two Koreas
}

\author{
Sam Un Oh, Eun-Hee Kim * (D), Kyoung-Min Kim and Myung-Kil Kim \\ Division of Global Forestry, Department of Forest Policy and Economics, National Institute of Forest \\ Science (NIFoS), 57 Hoegi-ro, Dongdaemun-gu, Seoul 02455, Korea; sameonoh@gmail.com (S.U.O.); \\ greenann@korea.kr (K.-M.K.); mkkim0201@korea.kr (M.-K.K.) \\ * Correspondence: jang0330@korea.kr; Tel.: +82-02-961-2897
}

Received: 28 August 2020; Accepted: 12 October 2020; Published: 20 October 2020

check for updates

\begin{abstract}
This study examined the development, direction, and characteristics of the North Korean forest restoration policy when compared to similar restoration policies established in South Korea. The success factors of South Korea's Forest Conservation and Afforestation Project were classified into four forest policy categories: (a) policy and system improvement, (b) evaluation and capacity building, (c) people's participation encouragement, and (d) restoration foundation creation. Similarities in terms of these aspects were found when compared with the Forest Restoration Battle of North Korea. For policy and system improvement, South Korea established the 1st and 2nd Forest Conservation and Afforestation Plans and transferred the control of the Korea Forest Service to its Ministry of Home Affairs. Similarly, North Korea established a forest development plan and a command unit for the Forest Restoration Battle. For evaluation and capacity building, South Korea utilized a tree monitoring and forestry association. North Korea is obtaining these effects through both a socialist competition movement and agroforestry. Further, South Korea aimed to promote people's participation through a nursery project, a tree planting movement, and a responsible afforestation system, whereas North Korea adopted agroforestry, a patriotic forest movement, and a responsible forest system. Finally, South Korea succeeded in replacing forest fuels with fossil fuels, clearing slash-and-burn fields, and performing erosion control. By comparison, North Korea is promoting the development of replacement fuels, such as ultra-high-grade anthracite coal and the formation of separate firewood forests. North Korea has revised its forest law to strengthen penalties for deforestation activities, such as anthropogenic forest fires, and replaced erosion control works with agroforestry, which allows for slope management. Among the four aspects, the largest difference was found for restoration foundation creation. Therefore, this area can provide a guideline for future inter-Korean forest cooperation.
\end{abstract}

Keywords: South Korea forest conservation and afforestation project; North Korea forest restoration battle; forest policy; afforestation; agroforestry

\section{Introduction}

North Korea's depleting forests have become a national priority. The country is currently implementing its Forest Restoration Battle program after adopting a joint decision based on the mobilization of residents and calling attention to the relationship between forest degradation and economic hardship [1]. According to the government, the aftermath of the Arduous March, a famine in North Korea that lasted from 1994-1998, led to the incessant cutting of plants for food and trees for firewood. Furthermore, there have been no standard forest fire prevention measures since the Arduous 
March. This prompted the government to include a separate forest sector in the 2015 national budget, with a $9.6 \%$ increase in the forestry budget allocation [2]. In addition, the government made forest policy a priority in July 2018 [3]. Thus, North Korea is using the Forest Restoration Battle to gauge the performance of its government. In addition, the forest restoration program is of bilateral importance to South Korea and North Korea because the two countries will undertake the project together and, according to the government, will share the restored land in the future.

As a follow-up to the implementation of the Panmunjom Declaration, the two Koreas held the Inter-Korean Forest Cooperation Subcommittee meeting on 4 July 2018. South Korea's Forest Conservation and Afforestation Project is considered to be a successful program. Therefore, the factors that led to the success of South Korea's program can be used as the benchmark for the performance of North Korea's Forest Restoration Battle. Moreover, the results of this analysis have many implications on inter-Korean cooperation in the forest sector.

Ecologist Lester Brown observed that South Korea's afforestation project was "in many ways a reforestation model for rest of world" [4]. At the 10th Ramsar Congress in 2008, Achim Steiner, Secretary-General of the United Nations Environment Program (UNEP) said, "The successful forestation of Korea is a pride of the world" [5]. The average forest growing stock per ha in South Korea, which indicates the density of forests, was $145.99 \mathrm{~m}^{3}$ in 2015. This is 12.9 times higher than the value of $11.34 \mathrm{~m}^{3}$ obtained in 1973, when the Forest Conservation and Afforestation Plan was established [6]. South Korea's forest growing stock per ha in 2010 was $126 \mathrm{~m}^{3}$, which exceeded the average of the Organization for Economic Cooperation and Development (OECD), $120 \mathrm{~m}^{3}$ [7]. Thus, the successful experience of South Korea's Forest Conservation and Afforestation Project could have implications on North Korea's forest restoration and the inter-Korean forest cooperation.

In this study, we first review the discussions on North Korea's Forest Restoration Battle among previous works. A study that analyzed the directions and composition of the North Korea's forest policy since 2012. [8] derived four broad characteristics from the policy: (a) establishment of forest policy strategy, (b) nationalization and systematization of forest management, (c) simultaneous promotion of forest restoration and rehabilitation, and (d) emphasis on forest science and technology. In addition, the background and content of agroforestry after 2012 were examined [9], and the press reports related to forestry in North Korea were classified and analyzed in major and sub-topics of forest development and forest protection [10]. The forest policies have also been summarized by era based on Rodong Sinmun and New Year's addresses [11].

Many studies have been conducted on South Korea's Forest Conservation and Afforestation Project. From these studies, the three main success factors of the afforestation drive are: government-led forestry administration, people's participation, and suppression of forest fuels [12]. The causes of the initial failure of the afforestation and the later success factors were also analyzed comprehensively. This study selected and conducted an intensive analysis of the five most efficient administrative cases of the afforestation policy: tree monitoring, clearance of slash-and-burn farmers, firewood forest development project, erosion control works, and the Saemaul Nursery project [13]. In addition, another study analyzed the core factors, albeit without the success factors of South Korea's afforestation [14]. This study selected replacement of domestic forest fuels with fossil fuels, afforestation, and firewood forest creation as the main success factors. The government-led afforestation policy was also examined as a core success factor of South Korea's afforestation [15]. This study demonstrates that afforestation is possible in a relatively short time, despite imperfect administrative methods or low economic development. In particular, the authors paid attention to the fact that inter-ministerial cooperation was enhanced to replace forest fuels with fossil fuels. Other notable studies related to South Korea's Forest Conservation and Afforestation Project include Success Factors of the Clearance Policy for Slash-and-Burn Fields in the 1970s [16], Afforestation Policy of South Korea [17], Analysis of Global Afforestation Success and Failure Cases [18], Forest Transition in Korea: Trends, Characteristics and Implications [19], and Analysis of Successful Cases of South Korean Afforestation [20]. 
Previous studies have discussed a similar problem highlighted in our study. The first example is a study that outlined methods to restore degraded forests in North Korea based on examples South Korea's forest conversation and afforestation policies [21]. This study derived the causes of North Korea's forest degradation and the success factors of South Korea's afforestation, and focused on proposing support areas for North Korea, such as alternative energy and food support. Another study pointed out the causes of North Korea's forest degradation and summarized lessons from the South Korean experience of forest restoration [22]. This study derived directions for the forest restoration project of North Korea from the four success factors of South Korea's forest restoration: transfer of control of Korea Forest Service to the Ministry of Home Affairs, national tree planting through public movement, success of the clearance policy for slash-and-burn fields, and forest resources survey to identify accurate forest status.

Previous studies focused on deriving reforestation plans for North Korea from the causes of North Korea's forest degradation and the success factors of South Korea's Forest Conservation and Afforestation Project. In contrast, this study focused on comparing and analyzing the contents of North Korea's Forest Restoration Battle based on the successful factors of South Korea's Forest Conservation and Afforestation Project. We selected six major contents and characteristics of North Korea's Forest Restoration Battle: establishment of a national forest management system, development of a socialist competition movement, continuous agroforestry, emphasis on ecological and environmental protection, forest science research, and efforts to find domestic alternative energies [8].

There are various factors involved in the fast restoration of degraded forests in South Korea. Previous examined economic growth, competitive market structure, improvement of agricultural productivity, establishment of person ownership, and reduced population growth [18]. However, this study only examines forest policies in previous studies that mentioned the success factors of South Korea's Forest Conservation and Afforestation Project. Furthermore, it does not mention the direct or indirect causes, including the respective social and historical backgrounds of the forest degradation of South and North Korea, the characteristics of the systems, or the domestic and international environments. A previous study that analyzed the forest transition theory and theories on the causes and countermeasures for deforestation for comparative study classifies the afforestation success factors into fundamental causes (external factors of forestry) and direct factors (internal factors of forestry) [23]. In this respect, this study has some limitations. However, the results of this study are still important considering that the current forest degradation status of North Korea is similar to that of South Korea in the 1970s; South Korea's reforestation today is regarded as a successful model, and we need to find the agenda and path of the inter-Korean forest cooperation.

The success factors of South Korea's Forest Conservation and Afforestation Project mentioned in previous works can be largely classified into four aspects: policy and system improvement, evaluation and capacity building, people's participation encouragement, and restoration foundation creation. This study compares and analyzes the afforestation projects of the two Koreas based on this classification of South Korea's success factors.

Before starting the comparative analysis of these four aspects, Table 1 briefly outlines the major social and economic indices of South Korea in 1973 when the Forest Conservation and Afforestation Project was launched, in comparison with those of North Korea in 2015 when the Forest Restoration Battle was started.

In the rough comparison of the status of South Korea and North Korea, the biggest differences are the total supply of primary energy and per capita supply of primary energy. The total supply of primary energy of South Korea was 2.9 times that of North Korea, and the per capita supply of primary energy of South Korea is 3.8 times that of North Korea. This suggests that the energy problem solution is a critical factor for the success of the afforestation project. 
Table 1. Comparison of socioeconomic status of South Korea in 1973 and North Korea in 2015.

\begin{tabular}{ccc}
\hline Classification & South Korea in 1973 & North Korea in 2015 \\
\hline Population (persons) & $34,103,149[24]$ & $25,243,917[25]$ \\
\hline Nominal GDP (US \$100 million) & $138[26]$ & $162[25]$ \\
\hline $\begin{array}{c}\text { GDP per capital (US\$) } \\
\text { Total supply of primary energy } \\
\text { (1000 TOE) }\end{array}$ & $406.0[25]$ & $648[25]$ \\
\hline $\begin{array}{c}\text { Per capita supply of primary } \\
\text { energy (TOE) }\end{array}$ & $25,010[27]$ & $8700[25]$ \\
\hline Total forest area (1000 ha) & $6586[6]$ & $0.36[26]$ \\
\hline Total growing stock $\left(\mathrm{m}^{3}\right)$ & $74[6]$ & $5285[28]$ \\
\hline
\end{tabular}

\section{Classification of South Korea's Success Factors and Comparison with North Korea's Forest Restoration Battle}

\subsection{Policy and System Improvement Aspect}

\subsubsection{South Korea}

Among the successful factors of South Korea's forest restoration, those that can be classified as the policy and system improvement aspect are the establishment of government-led Forest Conservation and Afforestation Plans, and the transfer of the control of Korea Forest Service to the Ministry of Home Affairs. The government-led Forest Conservation and Afforestation Plans consisted of two long-term plans: the first was the 10-year Forest Conservation and Afforestation Plan (1973-1978, hereinafter referred to as 'First Plan'), and the subsequent second 10-year Forest Conservation and Afforestation Plan (1979-1987, hereinafter referred to as 'Second Plan'). The results of these plans helped South Korea succeed in afforestation. The First Plan was established with the goal to quickly plant trees across one million ha by mobilizing State-level administrative powers, including finance and law enforcement. The goal of the First Plan was achieved in 1978, four years ahead of the planned date. The plan for general afforestation was to plant 2.1 billion trees across one million ha, but 2.9 billion trees were planted across 1.08 million ha in just six years from 1973-1978 [13]. Owing to the success of the First Plan, the Second Plan was reduced to a plan of the Korea Forest Service instead of the Ministry of Home Affairs. Moreover, the goal of this plan was not to improve afforestation, but to create a new national economic block in the mountains. To that end, the South Korean government established policies for the settlement of the national afforestation system, expansion of economic afforestation, the creation of large forest complexes, and creation of a regional complete afforestation principle. The policy keynotes were also changed from afforestation to economic forest development, mental guidance to technology propagation, heteronomous participation to national total participation, and regulation to development support [29]. The Second Plan achieved afforestation of 970,000 ha, including 80 units of economic forest complexes across 320,000 ha, continuous management of natural and young forests, and implementation of erosion control works [6].

The trends of growing stock per ha and growing stock per person indicate rapid growth of forest resources after 1973. As shown in Figure 1, the average growing stock per person increased annually by $14.42 \%$, reversing the trend of the previous period [19].

The transfer of the control of the Korea Forest Service from the Ministry of Agriculture and Forestry to the Ministry of Home Affairs means that the Forest Conservation and Afforestation Project will receive support from local administrative organizations and law enforcement administrative powers. The control was transferred in 1973 when the First Plan was launched. The reason for the revision of the Government Organization Act at the time was "for more efficient performance of forest administration" [30]. After this move, forest-related administrative organizations from the center 
to the provinces were strengthened, making it possible to mobilize the administrative organizations and labor of si (city), gun (county), and $g u$ (ward) for afforestation. The purpose of this move was to establish a tripartite system in which the governor, the mayor, and the ward chief were in charge of the comprehensive forest protection and management, the law enforcement chief was in charge of the protection and enforcement, and the forest public officials were in charge of the technical guidance. Based on these characteristics, Figure 2 shows the forest management organization system as indicated in the Forest Conservation and Afforestation Project Plan at the time. The original document is marked as ‘Responsibility Guidance System' [31].

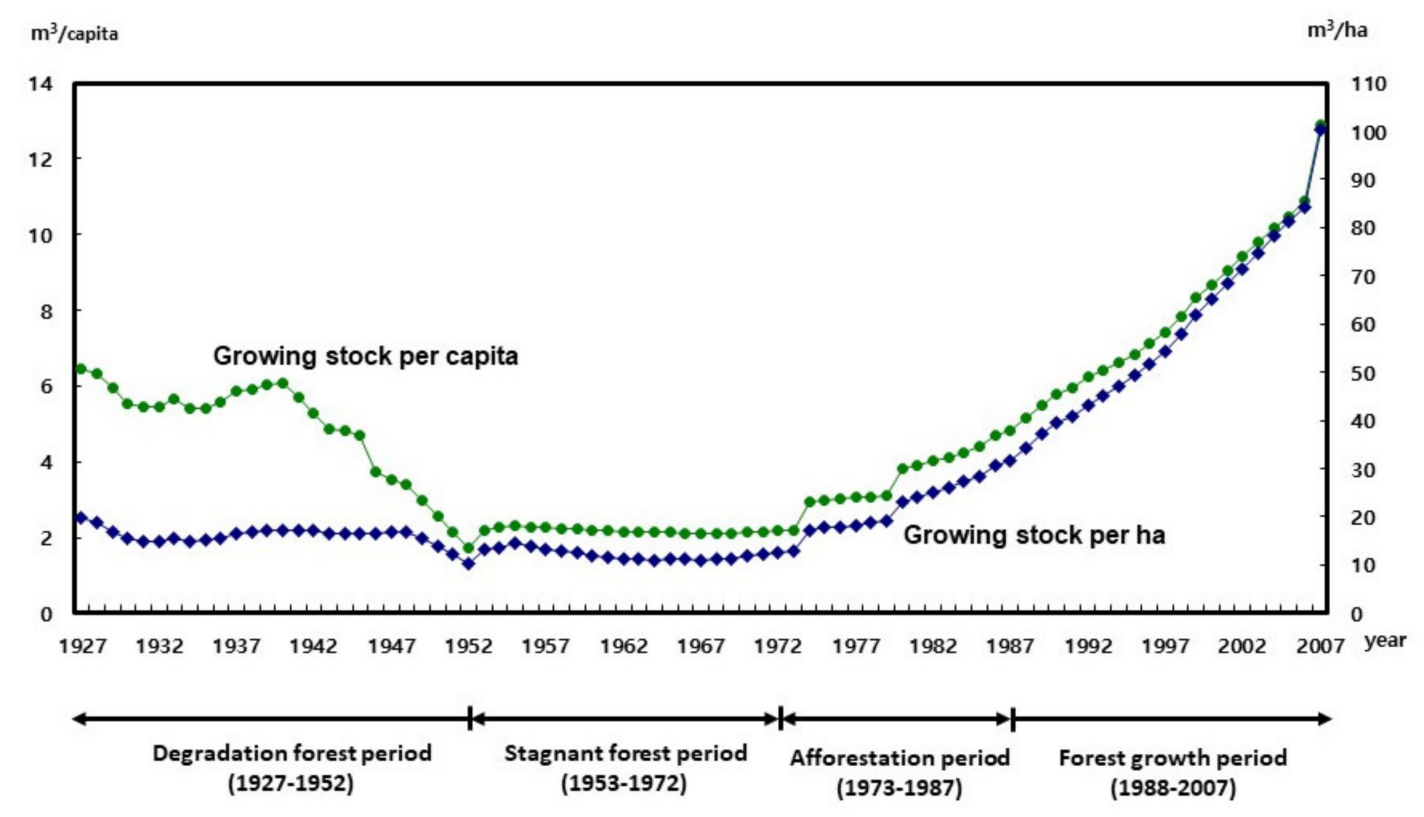

Figure 1. Changes in forest resources of South Korea (1927 2007).

The First Plan included strict forest protection policies. The mayor or ward chief could prohibit people from entering the forestland when they recognized that it was necessary within five years after the development and erosion control works of security forest, seed production forests, various test forests, and school practice forests. They could even prohibit people from entering mountains owned by civilians to prevent forest damage using the help of the law enforcement [30]. The transfer of power from the Korea Forest Service to the Ministry of Home Affairs was also effective in achieving the goal of 1 million ha of afforested land. Systematic and intensive promotion of the Forest Conservation and Afforestation Project through the establishment of the 1st and 2nd Plans and the transfer of the Korea Forest Service to the Ministry of Home Affairs, along with the Five-year Economic Development Plans, National Land Master Development Plans, and Saemaul Movement was one of the success factors of South Korea's Forest Conservation and Afforestation Project [32]. The government-led afforestation drive of South Korea is largely considered a success despite several problems, such as the weakening of response of mountain owners to the drive, which prevented proper management of forests in the successive years, and insufficient results in forest ecology, while the focus was on achieving afforestation goals [21]. 


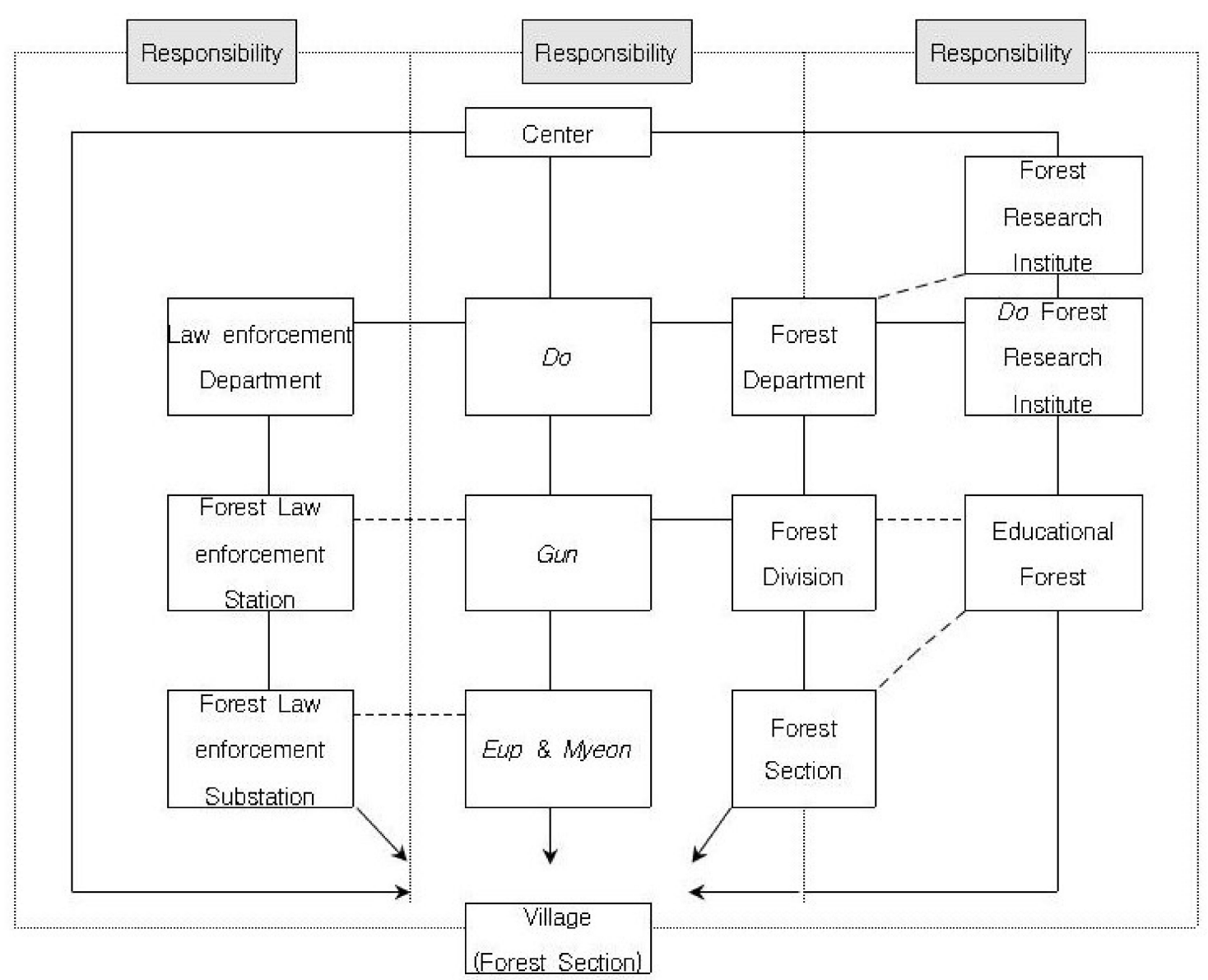

Figure 2. Forest Management Organization and System of South Korea (Responsibility Guidance System). *Do (province), Si (city), Gun (county), Gu (ward), Eup \& Myeon (town).

\subsubsection{North Korea}

At the start of the Forest Restoration Battle, North Korea established and strengthened their forest-related systems. First, the country established a set of forest development plans, the Total Forest Construction Plan, for a period of 30 years from 2013 2042, and Forest Development 10-Year Prospect Plans for a period of ten years from 2015 2024. According to data published by the government in 2014, North Korea established a Total Forest Construction Plan from 2013-2042. Furthermore, they also set a 10-year forest development goal from 2013 2022 (a goal of 1,682,000 ha).

However, according to a document related to the Forest Restoration Battle issued by North Korea in 2018 [33], the starting and ending years of the 10-year forest development plan were changed so that the first stage of the Forest Restoration Battle starts between 2015 2017, and the second stage starts between 2018 2024 [34]. Thus, the starting year of the forest development plan of North Korea was 2013 for the Total Forest Construction Plan and 2015 for the Forest Development 10-Year Prospect Plan. When we examined the documents by North Korea in detail, the number of total areas to be developed, including the artificial plantation area and natural regeneration area, were also different (Table 2).

The initial years of the 10-year mid- to long-term national plans are stated differently, presumably because the first stage of the 10-year plan was not established properly in 2013. Hence, the starting year was changed to 2015 with the establishment of the Forest Development 10-Year Prospect Plan. It is difficult to regard them as separate plans because the contents and values show little variation between the first stages of the 10-year plan in the Total Forest Construction Plan and the Forest Development 10-Year Prospect Plan. Moreover, the forest sector policies and systems were established in earnest in 2015, not 2013. A separate budget for the forest sector was first ratified in 2015. The third 
conference of the 13th Supreme People's Assembly in 2015 made a separate budget for the forest sector (which was increased by 9.6\%) [2]. In March 2015, the Cabinet adopted the Joint Decision of Central Committee of the Workers' Party of Korea, National Defense Commission, and Commander-in-Chief of the Armed Forces of DPRK based on the mobilization of all residents for the Forest Restoration Battle. In addition, a Forest Department was newly established under the Ministry of Land and Environmental Protection, and the Forest Restoration Battle Command System was also organized in do, si, and gun units nationwide [35]. In view of this, the original 10-year plan established in 2013 was changed and reset to a 10-year plan starting in 2015. This is a notable change because the planning system of North Korea in the past was rigid, and there was no room for adjustment.

Table 2. Comparison between the Total Forest Construction Plan and the Forest Development 10-Year Prospect Plan.

\begin{tabular}{|c|c|c|c|c|}
\hline \multicolumn{2}{|c|}{$\begin{array}{l}\text { Stage } 1 \text { Plan in Total Forest Construction } \\
\text { Plan (Based on Document Issued in 2014) }\end{array}$} & \multirow{5}{*}{$\Rightarrow$} & \multicolumn{2}{|c|}{$\begin{array}{c}\text { Forest Development 10-Year Prospect Plan } \\
\text { (Based on Press Reports in } 2015 \text { and Document } \\
\text { Issued in 2018) }\end{array}$} \\
\hline Period & $2013 \sim 2022$ & & Period & $2015 \sim 2024$ \\
\hline Total area & $1,682,000$ ha & & Total area & $1,986,500$ ha \\
\hline Artificial plantation area & $1,493,000$ ha & & $\begin{array}{l}\text { Artificial plantation area } \\
\text { (including grassland } \\
\text { creation) }\end{array}$ & $\begin{array}{l}1,755,000 \text { ha } \\
(316,000 \text { ha })\end{array}$ \\
\hline Natural regeneration area & 189,000 ha & & Natural regeneration area & 231,500 ha \\
\hline
\end{tabular}

The centralized planning system of North Korea has been implemented by a unified and detailed system of plans from the National Planning Commission to the lower economic units. A unified plan means that the plans of all divisions and units become unified plans of the nation. In contrast, a detailed plan, indicates that all economic sectors and businesses implement interlinked plans for management activities down to detailed items [36]. According to a report by the Korean Central News Agency in March 2015 on the Cabinet's decision regarding the Forest Development 10-Year Prospect Plan, the Cabinet stated, “Materials, equipment and funds must be planned and guaranteed through the Ministry of Land and Environmental Protection Forest Department in accordance with realistic conditions ... The preparation of the Forest Restoration Battle plan and the instruction of people's economic plan, etc. shall be undertaken by relevant units such as the National Planning Commission and Ministry of Land and Environmental Protection Forest Department, the Ministry of Forestry, and the Ministry of Agriculture". This suggests that they are considering realistic conditions while empowering the corresponding agencies [37]. To summarize, changing the period of the forest development plan indicates a characteristic after 2012 in North Korea that administrative power is exercised through policies that reflect reality. In the Kim Jong-Un era, changes in agricultural product purchase plans were also made. Previously, State purchases were regulated according to the farm's production plan, regardless of how much the central government provided farm supplies. However, in the new system, only the amount corresponding to the land use fees, irrigation fees, government-provided farm supplies, and the share of joint farm creation is set as the amount of national grain mandatory purchase [38].

Since the 10-year period was revised and presented again, the Forest Restoration Battle was launched as a nationwide project. Forest Restoration Battle command groups may have been organized in $d o$, si, and gun units and include the City Forest Management Office and other management organizations [39]. Figure 3 shows the forest management organization and system of North Korea by protection responsibility, management responsibility, and technical responsibility in accordance with the South Korean system. 


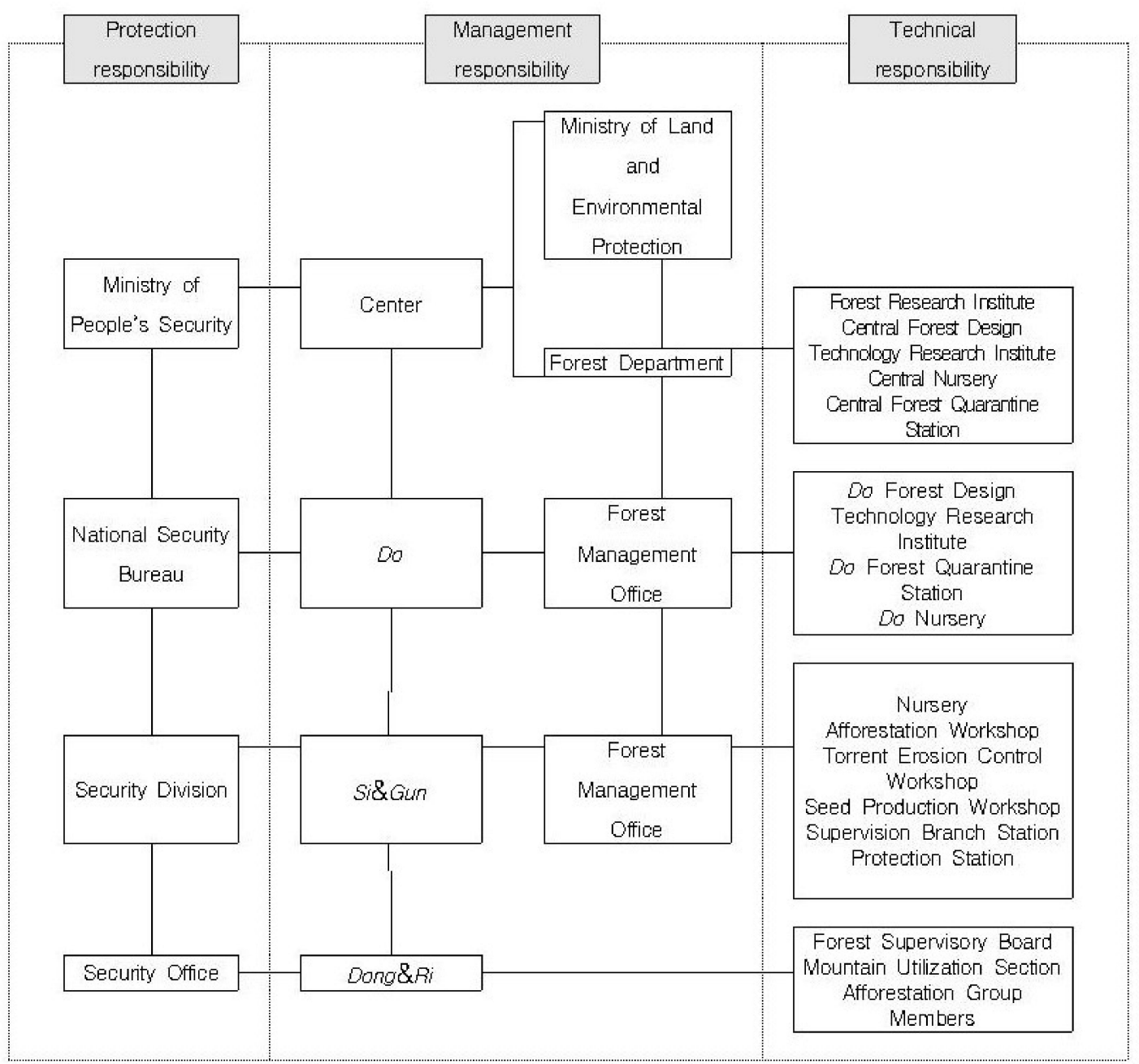

Figure 3. Forest management organization and system of North Korea in accordance with the system of South Korea.

From 2015 2017, more than 180 nurseries were constructed and remodeled, and the remote consultation system and nursery operation and command were also established among all si and gun nurseries across the country [40]. In April 2016, the Forest Fire Monitoring Information Service System was launched [41], and in July 2017, the Forest Resources Management Information System was developed [42]. The National Forest Fire Monitoring Information Service System is "a system that consists of forest fire information analysis, forest fire information notification, forest fire control command, and sends forest fire information combining digital stock map with forest fire-related image data from satellites to the corresponding units and $d o$, si, and gun command units of the Forest Restoration Battle to direct forest fire extinguishing situation". Kim Il-sung University, the Academy of Sciences, the National Aerospace Development Bureau, the Meteorological and Hydrological Bureau, and the Institute of Forest Science participated in the establishment of these systems [43]. They also revealed that the National Forest Resources Management Information System was developed through "establishment of national forest digital space data base by satellite data analysis technology, geographic information system technology, and forest fixed standard survey method" [43]. Table 3 outlines these systems related to North Korea's Forest Restoration Battle. 
Table 3. Systems related to North Korea's Forest Restoration Battle.

\begin{tabular}{|c|c|}
\hline \multirow[b]{2}{*}{ Plan } & Establishment of regional 10-year prospect plans and annual restoration plans \\
\hline & $\begin{array}{l}\text { - Combination of regional 10-year prospect plans and annual restoration plans with public } \\
\text { movements }\end{array}$ \\
\hline \multirow[b]{2}{*}{ Organization } & Organization of $d o$, si, and gun Forest Restoration Battle Command Systems \\
\hline & $\begin{array}{l}\text { - New establishment of Forest Department under the Ministry of Land and Environmental } \\
\text { Protection, and preparation of nationwide system for the Forest Restoration Battle }\end{array}$ \\
\hline \multirow{6}{*}{ Means } & Construction of central, do, si, and gun nurseries (more than 180, 2017) \\
\hline & $\begin{array}{l}\text { - Forest Restoration and Land Protection Workers Meeting (Feb. 2018) } \\
\text { : Discussion on tasks for the Forest Restoration Battle Stage } 1 \text { (2015-2017), and construction } \\
\text { and remodeling of more than } 180 \text { nurseries } \\
\text { : Establishment of remote consultation and operation command among national si and gun } \\
\text { maternal nurseries including Korean People's Army No. } 122 \text { Nursery, Ministry of Land and } \\
\text { Environmental Protection Central Nursery, Ministry of Urban Management Central Nursery }\end{array}$ \\
\hline & Construction of National Forest Fire Monitoring Information Service System (April 2016) \\
\hline & $\begin{array}{l}\text { - Organization of forest fire information analysis, forest fire information notification, and forest } \\
\text { fire control command } \\
\text { Collection of forest fire information by combining forest fire data from satellites with stock map } \\
\text { - Notification to do, si, and gun command units for Forest Restoration Battle and direction of } \\
\text { forest fire extinguishing situation }\end{array}$ \\
\hline & Organization of National Forest Resources Management Information System (July 2017) \\
\hline & $\begin{array}{l}\text { - Development and release of 'National Forest Resources Management Information System' } \\
\text { based on satellite data analysis technology, geographic information system technology, } \\
\text { and forest fixed standard survey method }\end{array}$ \\
\hline
\end{tabular}

Source: Prepared based on Rodong Sinmun and other sources.

\section{Evaluation and Capacity Building Aspect}

\subsection{South Korea}

Among the success factors of South Korea's Forest Conservation and Afforestation Project, the tree monitoring can be classified as the evaluation and capacity building aspect. This system verifies how many trees planted in mountains have survived until the autumn of the second year and how many seedlings planted in a nursery have survived and can be used for afforestation in the autumn of the same year or the succeeding year. The tree monitoring is considered to have played a decisive role in planting 2.9 billion trees across 1.08 million ha, which is an achievement of the First Plan. To improve transparency, the first tree monitoring was performed between different si's and gun's within the same $d o$, and the second was performed between different $d o$ 's nationwide under the supervision of the Korea Forest Service. Hence, this was referred to as a crosstree monitoring.

The tree monitoring was incentivized to contribute to high survival rates. When the survival rate was high, the Saemaul project received a special budget and incentive, as well as government prizes including the Presidential award. In the 1970s, the survival rate in the initial stage of the Forest Conservation and Afforestation Project was $87 \%$. Since 1977, it has increased to over $90 \%$. In particular, the survival rate in 1985 was $94 \%$, due in part to the drier spring season in South Korea [13]. Because the survival rate of plantations was used as a criterion to evaluate the performance of public officials, a healthy competition between the government officials and regions had begun. For this reason, the crosstree monitoring is regarded as a key policy and success factor for afforestation drives.

The development and distribution of forest science and technology have also contributed to the success of the afforestation project. In particular, five areas of forest science and technology-forest survey and inventory, tree improvement, seeds and nurseries, tree planting and tendering, and forest pest control—can be attributed to its success [44]. The erosion control project in the Yeongil District, 
which had failed due to specific soil problems, was successfully completed by introducing a special method. The devastated 4500 ha of land in this area, where more than 50 erosion control projects had been conducted and failed since 1907, was restored with the special method and specialist workers. The first forest survey project using aerial photographs enabled the identification of wastelands and recording statistics before research on the current status of forests and basic studies on the forestry industry were carried out. In the Second Plan, various measures were established in the areas of forestry technology research, education and training, experimental forestry research, breeding projects, and forestry mechanization for "the development and distribution of technology", further improving the research and introduction of science and technology in the forest sector [45]. Forest officials educated the local forest sections and residents, encouraging voluntary participation in tree planting, forest damage prevention, and forest protection. Forestry associations working for a national policy project took charge of the education in the dong(neighborhoods) and ri (neighborhoods) units across the nation [20].

\subsection{North Korea}

While South Korea achieved an increased tree survival rate through the tree monitoring, North Korea is aiming for this effect through the 'socialist competition movement'. This movement is one of the major policies of North Korea's Forest Restoration Battle. There are six major characteristics of the forest policy since 2012 in North Korea: establishment of a national forest management system, development of socialist competition movement, continuous agroforestry, emphasis on ecological and environmental protection, forest science research, and efforts to find domestic alternative energies [8].

The socialist competition movement is associated with survival rate because it is carried out by "the total evaluation of tree planting results by unit and individual with the survival rate at the top spot" [46]. For this evaluation, "the number of trees planted without survival rate guarantee or meeting the requirements of technical regulations will be unconditionally subtracted from the results" [39]. Experience discussion meetings with the units and workers who raised the survival rate through good planting are held, or propaganda paintings, breaking news boards, competition chart by unit, slogans, and mottos are displayed [47]. Structures such as military forest development, 10-year prospect drawings, and forest restoration socialist competition illustrations (e.g., seedling production, tree planting, and protection management achievements) are placed in large population areas. Furthermore, the competition points are subdivided (e.g., battle target presentation, obligatory items, objects of participation in competition, specification of competition period). Particularly, as the competitions are now performed by sector and category instead of among nurseries, the objects of competitions have been expanded and subdivided to businesses, cooperative farms, forest supervisory boards, and nonproduction units. The survival rate guarantee was set as an important evaluation criterion, and the competition meetings were held in mountains instead of offices to enhance the effect [48]. Thus, socialist competitions are being carried out in various names and methods, such as the demonstration project [49], and the leading, learning, and experience exchange movement [50]. For a local case where there was a frenzy to learn the example of a forestry supervisory board, Rodonog Sinmun would encourage people, saying "The Forest Restoration Battle will be more active if all the units follow this example, learn from each other, and create a fierce competition fever to become a model unit" [51]. Regarding socialist competition, Rodong Sinmun wrote in an editorial, "As members of the Party and workers from all over the country actively raised the socialist competition fever, the first stage of the Forest Restoration Battle was carried out brilliantly" [52]. Therefore, the socialist competition movement of North Korea has many similarities with the tree monitoring of South Korea, which rated the survival rate. However, unlike the South Korean case where competition was promoted through incentives, the incentives of North Korea are speculated to be insufficient.

North Korea has also been emphasizing the importance of scientific and technological research in the forest sector [8]. Rodong Sinmun reported that, "the problems in the scientification, industrialization, and intensification of the production of seedlings should be solved with the power of science and 
technology" [53], publicizing its achievements in forest science research. The country promoted this atmosphere by holding the National Forest Machinery Exhibition in January 2016 and awarding participants at the National Forest Science and Technology Presentation in September 2016. In the same context, the Forest Science Department was established at Kim Il-sung University in 2017. The Department was established with the expectation of "creating a new base for developing human resources that play a key role in the development of innovative forestry science and technology" [54]. In April 2018, the Forest Research Institute held a groundbreaking ceremony in the Daeseongsan Mountain district in Pyongyang to further emphasize the importance of research on forest science and technology.

With respect to education, various projects presented in the 'Agroforestry Strategy and Action Plan' [55] can be cited as examples. This plan states "performance of workshops, employee training, demonstration training, field visits for the continuous capacity building of agroforestry staff". Furthermore, the roles of educational institutions are presented as "publicizing the success stories, experiences, failures, and lessons to the public". Another allocated project is to "place capable experts in professional research institutes to cultivate technology and accumulate knowledge and information."

\section{People's Participation Encouragement Aspect}

\subsection{South Korea}

The First Plan achieved its goal four years ahead of the planned date because of the effective participation of citizens through the National Planting Principle [17]. A few systems were implemented to promote people's participation. The first was the nursery project. The government financed the beginning of a nursery and ensured its income by purchasing all the seedlings produced at market prices [13]. The government also encouraged residents' participation in the nursery project by distributing Italian poplar and chestnut seedlings to villages for free. Rather than creating a technical nursery using technicians, nurseries were established through national mobilization because of the government's strong will at the time to green the forests in a short period of time.

The second system was a national tree planting movement and a responsible afforestation system. In principle, villages performed joint forest development within $2 \mathrm{~km}$ from the center of the village, and the responsible afforestation system was applied to organizations. Forests were developed in mountains owned by schools and individuals. Companies that own forests were required to plant forests, while those that do not own forests were recommended to plant forests [14].

\subsection{North Korea}

The North Korean policy comparable in terms of intention, purpose, and importance to the nursery project of South Korea is agroforestry. Agroforestry involves cultivating crops, rearing livestock, and growing and managing trees and forests in one place. Agroforestry has been drawing attention as a means for sustainable agriculture through international conventions such as the United Nations Framework Convention on Climate Change (UNFCCC) and the Convention on Biological Diversity (CBD). Furthermore, agroforestry model projects have been carried out in various areas to promote agricultural productivity and eco-friendly farming [56]. In North Korea, the agroforestry technique is called sloping agricultural land technology (SALT). Trees are planted approximately 4-5 m apart along the contour to form fences, with food crops (bio protective belts) such as beans planted between them [9]. North Korea ratified agroforestry regulations in the Forest Law amended in 2013 and established the Agroforestry 10-Year Strategy and Project Plan (2015-2024). The country is actively recommending agroforestry as an "effective land management method in preventing forest destruction and increasing the utilization rate of forest land to achieve continuous stability and development of food production" [57]. 
Agroforestry in North Korea shows similarities with the nursery project of South Korea in that they encourage people's participation by ensuring income through the nursery project. Agroforestry involves planting edible fruit trees with high economic value and also plant crops below the trees [57], and the mountain utilization sections with agroforestry could exchange and sell their crops in markets [58]. In a 2017 interview, Dr. Jianchu Xu of the World Agroforestry Center revealed that some of the crops produced through agroforestry are paid to the government while the remainder are distributed to the people. This is in agreement with the trend of the Cooperative Farm Responsibility Management System, which generally strengthens the management rights of cooperative farms by expanding their planning and selling rights under the current government [59]. Furthermore, residents could select tree species as part of the method of social participation. They introduced a tree species selection method, which involves scoring the trees by the criteria of versatile (economic and ecological), rapid growth or high biomass yield, indigenous or locally available species, lower competition with other crops for light, water, and nutrition, lower development cost, and lower pest damage [60]. Hence, agroforestry is similar to the nursery project of South Korea because it is attracting the participation of residents from the selection of crop species.

The North Korean systems equivalent of the national tree planting movement and responsible afforestation system of South Korea are the responsible forest system and the patriotic forest movement. The responsible forest system is a system that promotes competitive management by distributing a certain area of land to each institution, enterprise, school, and organization, who take charge of afforestation, forestry, forest fire extinguishing, and pest control. In the 1980s, the responsible forest system was expanded to public organizations such as the Youth League forests, the Union of Socialist Workers Youth of Korea forests, and the Chosun Democratic Women's Federation forests. Each cooperative farm was given a forest of around 99 ha (100 jeongbo: a Korean unit of measurement) [61]. This responsible forest system was further strengthened with the Forest Restoration Battle, and the responsible system is enforced on every region, business, unit, household, and individual [62]. The patriotic forest movement has been encouraged by the Standing Committee of the Supreme People's Assembly by announcing an ordinance to establish the titles of "Socialist Patriotic Forest" and "Model Forest Worker". The Standing Committee stated that they established these titles to "praise units and military forces that set a good example in the forest development and protection management projects to refresh the appearance of the national land" [63].

\section{Restoration Foundation Creation Aspect}

\subsection{South Korea}

In this aspect, three detailed success factors are identified: replacement of forest fuels and creation of firewood forests, clearance of slash-and-burn fields, and erosion control works. First, replacing forest fuels that were originally used for domestic fuels with fossil fuels is a core success factor. If the fuel consumption trends of 1955 continued, most forests in South Korea would have been depleted in less than a decade. Bae and Lee [14] surmised that woods corresponding to $17 \%$ of the total growing stock in 1955 and other forest fuels, such as branches and leaves and byproducts such as roots, were used for or subject to use as domestic fuels. Amid the promotion of anthracite production in 1956 and the ban on forest fuels in cities in 1958, forest fuels were replaced with anthracite in the 1960s for home fuels in cities [23]. Consequently, only 5.2\% of urban residents in 1970 used forest fuels for domestic cooking and heating energy. Thus, afforestation began to take effect with the ratifying of the fossil fuel replacement policy. The absolute reduction of forest fuels for domestic fuels in rural areas also played an important role in reducing the forest fuel consumption. During the 1980s, the forest fuels in rural areas were replaced with gas for cooking and coal for heating [23].

Meanwhile, as part of the First Plan, approximately 643,000 ha of firewood forests were grown. In addition, village firewood forests were expanded to increase the supply of forest fuels, and sunflowers and bush clovers were planted in large quantities. Furthermore, to systematize the collection of forest 
fuels, each village was assigned a pre-determined collection area and its residents were instructed to work jointly in the presence of officials. In addition, Saemaul furnaces were improved in line with the expansion of coal supply. Thus, fuel conversion plans were implemented gradually [32].

Second, forests were primarily restored by clearing slash-and-burn fields. These fields [64] were a direct cause of forest degradation, and success in the clearance policy for slash-and-burn fields was directly associated with the success of afforestation. Slash-and-burn fields were devastating because they had a wildfire spreading risk, and farmers had to migrate to new fields every year. The clearance policy had to rehabilitate approximately 300,000 slash-and-burn farmer households from 1967 1978, which corresponded to 6-7\% of the total population. The full-scale clearance policy for slash-and-burn fields was implemented in 1974 with the establishment of the '5-year plan for the clearance of slash-and-burn fields'. It was completed in 1979 instead of 1978, when some of the remaining slash-and-burn farmers were rehabilitated and resettled with their due consent. The farmers were paid an initial subsidy of 130,000 KRW (South Korean Won) and a final subsidy of 270,000 KRW. Their houses were demolished and new trees were planted at the site and the farmers were relocated to cities or nearby villages. The farmers could retain the site if they chose to, provided that they were willing to purchase the land in yearly installments. This way, the land was registered in their names. The government also took steps to ensure transparency and efficiency of the clearance policy by installing a Clearance of Slash-And-Burn Fields Deliberation Committee at the Central and provincial levels [13]. The clearance policy for slash-and-burn fields succeeded because of the decrease in the lowest level farmers who were likely to be slash-and-burn farmers and the forest resource survey technology using aerial photographs advanced to enable identification of the locations of slash-and-burn farmers [65].

Finally, one aspect of the forest restoration foundation creation was the erosion control works in 484,000 ha undertaken from 1961-1979, which restored $92.5 \%$ of wastelands. A representative example is the erosion control works at the Yeongil district in Pohang. The works in this area (approximately 4538 ha) mobilized a budget of 3.8 billion KRW and a manpower of 3.55 million persons for five years from 1973-1977. At that time, workers planted trees on the slopes with tethers for safety, while other workers displaced good soil from the foot of the slope to cover up the cultivated site [66]. The Second Plan also continued the erosion control works. All the wastelands were completely restored by additionally restoring approximately 36,000 ha of wasteland with a total budget of 177.9 billion KRW. These control works were assigned to paid laborers by mobilizing rural workers in the off-farming season [13].

\subsection{North Korea}

While South Korea has developed firewood forests by replacing forest fuels, North Korea is creating firewood forests while developing alternative fuels. Thus, North Korea is emphasizing measures to lower forest dependence. The direction is to "actively generalize the experiences of units that have solved the fire problem with methane gas, soft wood, or ultra-high-grade anthracite coal in order to solve the fire problem on their own in all regions" [67]. Therefore, they are recommending ultra-high-grade anthracite coals, which are common in Gangwon-do, citing the case of converting ultra-high-grade anthracite coal [68] into domestic fire wood in rural areas. Through conversion of coal into methane gas at households in Yeontan-gun, Jangun-ri was recognized as not only solving the firewood problem, but also helping the forest protection project. They are also encouraging ways to reduce timber consumption by sector, such as the development of sleeper protection techniques in the rail transport sector as part of "measures to extend the life of wood and reduce forest dependence" [69].

With respect to the creation of firewood forests, they have continuously emphasized the firewood forest creation project through acacia and other trees [70]. They are also focusing on circular logging while solving the firewood problem through poplar trees [71]. Circular logging, which has been in place since August 1963, divides large forest into zones, and the trees are circularly felled in each area 
according to a plan [35]. "This method can satisfy people's economic needs for logs without depleting forest resources" [72].

Second, North Korea's problem of slash-and-burn fields also may have been solved. Like South Korea, North Korea also supported the slash-and-burn farmers to move to farms and company-owned properties at first. The country took actions in 1949 through Cabinet Decision No. 167 to "guarantee conditions for slash-and-burn farmers to enter production workplaces and to improve their material and cultural life". According to this decision, the government-leased homes for free for three years and provided other benefits, such as partial exemption of student tuitions and granting loans. Furthermore, the lodging and transformation expenses of the slash-and-burn farmers for moving to other workplaces were borne by the employing organizations, and farmers received training for skills for at least three months [73].

Article 25 'Prohibitions in Forest Areas' of the Forest Law amended on 11 March 2015 specified prohibited behaviors, such as entering a mountain and causing a fire, thus, strictly monitoring and controlling fires. They strengthened the regulations and orders in forest development by adding punishment rules for each behavior in Article 47 'Administrative Responsibility' as well. In the "Act on Clearance of Slash-and-Burn Fields" established in 1966, South Korea converted slash-and-burn fields developed on slopes of $20^{\circ}$ or higher into forests [74], whereas North Korea has a policy to create forests on slopes of $30^{\circ}$ or higher [75].

Third, it is difficult in North Korea to perform erosion control works as in South Korea, but its agroforestry initiative is achieving the desirable effects of erosion control because agroforestry prevents soil loss from cultivated slopes. A representative example is the Sloping Agricultural Land Technology (SALT). SALT is a type of agroforestry that plants shrubs or tall trees with nitrogen fixing capacity $3-5 \mathrm{~m}$ along the perimeter of the cultivation area on slopes. It can not only reduce fertilizer usage because the vegetation in the perimeter fixes nitrogen, but also prevents soil loss [32]. According to a document released in 2015, North Korea uses lands with slopes greater than $30^{\circ}$ for forest development, between $15 \sim 30^{\circ}$ for agroforestry, and less than $15^{\circ}$ for tillage. If the soil depth is less than $20 \mathrm{~cm}$, forest restoration can occur when the slope is above $20^{\circ}$ [76]. Furthermore, various technical studies related to slopes and soil erosion have been published through science and technology magazines in North Korea, such as Geology and Geography and Technical Innovation [77,78]. Rodong Sinmun's torrent erosion control works [78] and continuous research on erosion control engineering can also be found, though they are few in number. Papers related to erosion control engineering can be found in North Korean science and technology magazines such as Geology and Geography and Agricultural Irrigation.

Table 4 outlines the contents and numbers of South Korea's Forest Conservation and Afforestation Project in comparison with North Korea's Forest Restoration Battle.

Table 4. Comparison of major data between South Korea's Forest Conservation and Afforestation Project and North Korea's Forest Restoration Battle.

\begin{tabular}{|c|c|c|}
\hline Classification & $\begin{array}{c}\text { South Korea's Forest Conservation and } \\
\text { Afforestation Project }\end{array}$ & North Korea's Forest Restoration Battle \\
\hline Forest development & $\begin{array}{l}\text { 1st } 10 \text {-year Forest Conservation and } \\
\text { Afforestation Plan was completed in } \\
6 \text { years (Planted } 2.9 \text { billion trees in } \\
1.08 \text { million ha in just } 6 \text { years from } \\
1973 \text { to 1978) }\end{array}$ & $\begin{array}{l}\text { - Forest Development 10-Year } \\
\text { Prospect Plan (Goal is to artificially } \\
\text { plant in 1,755,000 ha from } 2015 \text { to } \\
\text { 2024. Planted 2,351,520,000 trees in } \\
607,942 \text { ha from } 2015 \text { to } 2017 \text { ) }\end{array}$ \\
\hline $\begin{array}{l}\text { Replacement of } \\
\text { forest fuels }\end{array}$ & $\begin{array}{l}\text { - Completed the development of } \\
\text { firewood forests of } 643,000 \text { ha in } 1977 . \\
\text { - The firewood was replaced with gas } \\
\text { for cooling and coals for heating in } \\
\text { rural areas during the } 1980 \mathrm{~s} \text {. }\end{array}$ & 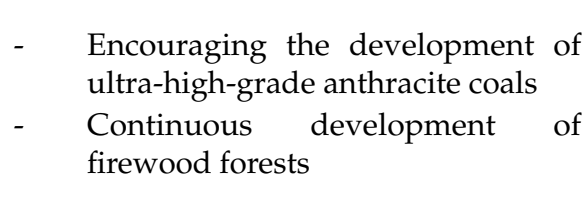 \\
\hline
\end{tabular}


Table 4. Cont.

\begin{tabular}{|c|c|c|}
\hline Classification & $\begin{array}{c}\text { South Korea's Forest Conservation and } \\
\text { Afforestation Project }\end{array}$ & North Korea's Forest Restoration Battle \\
\hline $\begin{array}{l}\text { Clearance policy for } \\
\text { slash-and-burn } \\
\text { fields }\end{array}$ & 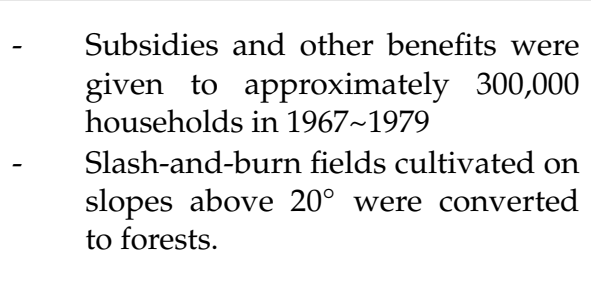 & $\begin{array}{l}\text { - Punishment was strengthened with } \\
\text { the amendment of the Forest Law } \\
\text { in } 2015 \text { (provision related to forest } \\
\text { fire in Article } 25 \text { of Forest Law } \\
\text { 'Prohibitions in Forest Areas') } \\
\text { - Forest development on slopes } \\
\text { above } 30^{\circ}\end{array}$ \\
\hline $\begin{array}{l}\text { Erosion control } \\
\text { works }\end{array}$ & $\begin{array}{l}\text { Total manpower of } 3.55 \text { million } \\
\text { people for } 5 \text { years (1973 1977) were } \\
\text { mobilized with a budget of } 3.8 \text { billion } \\
\text { KRW for restoration of } 4538 \text { ha. } \\
\text { - Special engineering methods and } \\
\text { special workers were utilized. }\end{array}$ & $\begin{array}{l}\text { - Encouragement of agroforestry to } \\
\text { prevent soil erosion and reduce } \\
\text { soil loss (Agroforestry on slopes of } \\
15 \sim 30^{\circ} \text { ) } \\
\text { - } \quad \text { Studies related to erosion control are } \\
\text { in progress. }\end{array}$ \\
\hline
\end{tabular}

The following Tables 5 and 6 outlines the success factors of South Korea's Forest Conservation and Afforestation Project in comparison with the main contents of North Korea's Forest Restoration Battle.

Table 5. Main contents of the North Korean forest policy and improvement measures.

\begin{tabular}{clll}
\hline Classification & \multicolumn{1}{c}{ Main Contents } & \multicolumn{1}{c}{ Improvement Measures } \\
\hline Afforestation & - & $\begin{array}{l}\text { Artificial planting in 1,755,000 ha in } \\
2015 \sim 2024 \text { (Planting 2,351,520,000 trees } \\
\text { in 607,942 ha in 2015 2017) }\end{array}$ & $\begin{array}{l}\text { Technology support for improving } \\
\text { survival rate } \\
\text { Support for materials such as } \\
\text { seedlings and fertilizers }\end{array}$ \\
\hline $\begin{array}{c}\text { Forest recovery and } \\
\text { renovation }\end{array}$ & - & $\begin{array}{l}\text { Continuation and expansion } \\
\text { of agroforestry } \\
\text { Emphasis on forest science and } \\
\text { technology research }\end{array}$ & $\begin{array}{l}\text { Cultivation of techniques and } \\
\text { abilities for policy implementation } \\
\text { Reinforcement of science and } \\
\text { technology such as erosion control }\end{array}$ \\
\hline $\begin{array}{l}\text { Replacement of } \\
\text { forest fuels }\end{array}$ & $-\quad \begin{array}{l}\text { Encouragement of the development of } \\
\text { ultra-high-grade anthracite, etc. } \\
\text { Continuation firewood } \\
\text { forest development }\end{array}$ & $\begin{array}{l}\text { Strengthening of the development } \\
\text { of alternative energies } \\
\text { Development of bio-energy and } \\
\text { improvement of species }\end{array}$ \\
\hline
\end{tabular}

Table 6. Success factors of South Korea's Forest Conservation and Afforestation Project in comparison with the main contents of North Korea's Forest Restoration Battle.

\begin{tabular}{|c|c|c|}
\hline & South Korea & North Korea \\
\hline \multirow{2}{*}{$\begin{array}{l}\text { Policy and system } \\
\text { improvement }\end{array}$} & $\begin{array}{l}\text { 1st and 2nd Forest Conservation and } \\
\text { Afforestation Plans }\end{array}$ & $\begin{array}{l}\text { 10-year Prospect Plan and Total Forest } \\
\text { Construction Plan (30 years) }\end{array}$ \\
\hline & $\begin{array}{l}\text { Transfer of Korea Forest Service to the } \\
\text { Ministry of Home Affairs }\end{array}$ & $\begin{array}{l}\text { Development of Forest Restoration Battle } \\
\text { Command System }\end{array}$ \\
\hline \multirow{2}{*}{$\begin{array}{l}\text { Evaluation and } \\
\text { capacity building }\end{array}$} & Crosstree monitoring (survival rate) & $\begin{array}{l}\text { Socialist competition movement } \\
\text { (survival rate) }\end{array}$ \\
\hline & $\begin{array}{l}\text { Forestry associations in charge } \\
\text { of education }\end{array}$ & Agroforestry capacity building \\
\hline \multirow{2}{*}{$\begin{array}{c}\text { People's } \\
\text { participation } \\
\text { encouragement }\end{array}$} & Nursery project (village income creation) & Agroforestry (permission of crop selling) \\
\hline & $\begin{array}{l}\text { Tree planting movement and responsible } \\
\text { afforestation system }\end{array}$ & $\begin{array}{l}\text { Patriotic forest movement and responsible } \\
\text { forest system }\end{array}$ \\
\hline
\end{tabular}


Table 6. Cont.

\begin{tabular}{ccc}
\hline & South Korea & North Korea \\
\hline $\begin{array}{c}\text { Restoration } \\
\text { foundation creation }\end{array}$ & $\begin{array}{c}\text { Creation of firewood forests and } \\
\text { replacement with fossil fuels }\end{array}$ & $\begin{array}{c}\text { Development of alternative fuels and } \\
\text { creation of firewood forests }\end{array}$ \\
\cline { 2 - 3 } & $\begin{array}{c}\text { Clearance of slash-and-burn fields and } \\
\text { erosion control works }\end{array}$ & Replacement with agroforestry \\
\hline
\end{tabular}

\section{Conclusions}

In this study, a comparative analysis of South Korea's Forest Conservation and Afforestation Project, which started in 1973, and North Korea's Forest Restoration Battle, which started in earnest in 2015, was conducted, with many similarities were found between them. The success factors of South Korea's Forest Conservation and Afforestation Project selected from previous studies were broadly classified into policy and system improvement, evaluation and capacity building, people's participation encouragement, and restoration foundation creation. When these success factors were compared with the main contents of North Korea's Forest Restoration Battle, several commonalities were found in the intentions, purposes, and contents of the projects. All the undertakings of North Korea compared with the success factors of South Korea in the four aspects were major forest policies. Based on this research, it was concluded that North Korea's Forest Restoration Battle was on the precipice of success. In this respect, detailed bilateral exchanges and sectorial cooperation between the two countries are possible and can be beneficial.

The comparison results can be summarized as follows. First, in the aspect of policy and system improvement, the Government of South Korea established the Forest Conservation and the Afforestation Plan and transferred the control of the Korea Forest Service to the Ministry of Home Affairs, while North Korea established forest development plans and Forest Restoration Battle command units. Second, in the aspect of evaluation and capacity building, South Korea utilized the tree monitoring and forestry associations. North Korea is achieving these effects through the socialist competition movement and agroforestry. Third, South Korea aimed for people's participation through the nursery project, tree plantation movement, and responsible afforestation system, whereas North Korea is adopting agroforestry, the patriotic forest movement, and the responsible forest system. Finally, South Korea created the foundation for forest restoration through the success achieved in the replacement of forest fuels with fossil fuels and the clearance of slash-and-burn fields and erosion control works. In contrast, although North Korea is encouraging the development of alternative fuels such as ultra-high-grade anthracite coal, the results are not substantial. North Korea amended the Forest Law to heighten penalties for forest damage behavior and is promoting agroforestry for slope management.

To summarize, the largest differences between the approaches of the two nations are found in the restoration foundation creation. This can be a key to predict the future success or failure of North Korea's forest policy and a model for inter-Korean forest cooperation. While South Korea successfully replaced forest fuels with fossil fuels, North Korea is still developing alternative fuels and at the same time growing firewood forests. In addition, while South Korea successfully completed erosion control works, North Korea seems to be replacing erosion control works with agroforestry. Therefore, inter-Korean exchange and cooperation projects will be necessary for the bio-energy development and improvement of species, the improvement of technology for erosion control works, and the development of agroforestry technology.

Author Contributions: Conceptualization, S.U.O. \& E.-H.K.; methodology, S.U.O. \& E.-H.K.; validation S.U.O., E.-H.K., K.-M.K.; resources \& investigation, S.U.O. \& E.-H.K.; writing-original draft preparation, S.U.O., writing-review and editing, E.-H.K., K.-M.K. \& M.-K.K.; All authors have read and agreed to the published version of the manuscript.

Funding: This research received no external funding.

Conflicts of Interest: The authors declare no conflict of interest. 


\section{References and Notes}

1. Kim, J.U. Let the Entire Party, Military Forces, and People do their Best to Fight for the Forest Restoration Battle to Create Thick Green Forests in the Mountains of our Homeland. Rodong Sinmun, 27 February 2015.

2. Kim, S.J. Assessment of Third Conference Results of 13th Supreme People's Assembly of North Korea. Korea Institute for National Unification. Available online: http://www.kinu.or.kr/issue/index.jsp?p age $=1 \&$ num $=1084 \&$ mode $=$ view $\&$ field $=\&$ text $=\&$ order $=\&$ dir $=\& b i d=D A T A 01 \& s e s=\&$ category $=1$ http: //repo.kinu.or.kr/handle/2015.oak/2398/ (accessed on 13 January 2020).

3. Rodong News Agency. Dear Supreme Leader Kim Jong-Un Gave on-the-Spot Guidance in a Tree Nursery in Gangwon-Do. Rodong Sinmun, 27 July 2018.

4. $\quad$ Brown Lester, R. Plan. B 2.0: Rescuing a Planet Under Stress and a Civilization in Trouble; W. W. Norton \& Company: New York, NY, USA, 2016; p. 147.

5. We Need Green Welfare More in this Era. Seoul Newspaper, 8 January 2015.

6. Korea Forest Service. Available online: http://www.forest.go.kr/ (accessed on 21 February 2020).

7. Afforestation' Promotion and Success Factors. Farmers Newspaper, 22 July 2015.

8. Oh, S.U.; Kim, E.H.; Kim, K.M. Characteristics of Forest Policy in the Kim Jong-Un Era. North Korean Stud. 2018, 14, 101-133.

9. Kim, S.Y.; Park, S.Y.; Park, K.S. A Study on New Change of Forest Management in DPRK by Introducing Agroforestry of Sloping Land Management. Korean J. Unification Aff. 2016, 28.

10. Yi, J.M.; Song, M.K.; Park, K.S. An Analysis on North Korean Forest-Related Articles in Kim Jong-Un Era (2012-2016): Focusing on Forest Restoration Status and Problems. Korean J. Unification Aff. 2017, 29.

11. Jeon, B.K. A Study on the Forest Policy and Its Environment of Democratic People's Republic of Korea: Focusing on New Year's Messages and Rodong Newspaper. Ph.D. Thesis, University of North Korean Studies, Seoul, Korea, 2016.

12. Park, K.S. Analysis of Afforestation Success Factors. Collection of Forest Science Papers. 1995.

13. Lee, K.-J. A Case Study on Effective Policy Enforcement: Afforestation Administration (Focusing on Policy Enforcement Process and Post-Supervision System), Governance Case Studies; Korea Development Institute: Gangwon-do, Korea, 2014.

14. Bae, J.S.; Lee, K.B. Success Factors for Korea's Afforestation; National Institute of Forest Science: Seoul, Korea, 2006.

15. Bae, J.S.; Joo, J.W.; Kim, Y.S. Forest Transition in Korea: Reality, Path and Drivers. Land Use Policy 2012, 29, 198-207. [CrossRef]

16. Lee, K.B.; Bae, J.S. Factors of Success of the Clearance Policy for Slash-and-Burn Fields in the 1970s. J. Korean For. Soc. 2007, 96.

17. Jeong, J.S. Afforestation Policy of Korea; KDI School of Public Policy and Management: Sejong, Korea, 2008.

18. Yoon, Y.C. Analysis of Global Afforestation Success and Failure Cases; Korea Forest Service: Daejeon, Korea, 2004.

19. Bae, J.S. Forest Transition in Korea: Trends, Characteristics and Implications. J. Korean Soc. For. Sci. 2009, 98, 659-668.

20. Kim, B.S. Analysis of Successful Cases of Korean Afforestation; The Korean Association for Public Administration: Jongno-gu, Korea, 2009. Available online: http://dl.nanet.go.kr/law/SearchDetailView.do?cn=MONO120103 3414 (accessed on 20 March 2020).

21. Kim, Y.H. A Study on Ecological Restoration Measures for the Degraded Land in North Korea: Focusing on Korea's Restoration Policy. North Korean Stud. Rev. 2005, 9, 21-48.

22. Park, K.S.; Park, S.Y. The Rehabilitation of North Korea's Devastated Forest with the Focus on the Case of Korea. North Korean Stud. 2012, 8, 133-159.

23. Bae, J.S.; Joo, R.W.; Lee, K.B. Success Factors for South Korea's Afforestation; National Institute of Forest Science: Seoul, Korea, 2010.

24. Major Population Indices. National Statistics Portal. Available online: http://www.kosis.kr/ (accessed on 11 February 2020).

25. UN Data. Statistics Korea. Available online: http://www.kostat.go.kr/ (accessed on 11 February 2020).

26. Annual Indices. Statistics Korea. Available online: http://www.kostat.go.kr/ (accessed on 11 February 2020).

27. Korea Energy Economics Institute. Available online: http://www.keei.re.kr/ (accessed on 11 February 2020).

28. FAO Data. Available online: http://www.kostat.go.kr/ (accessed on 11 February 2020). 
29. Oh, S.U.; Kim, E.H.; Kim, K.; Park, S.Y. A Comparative Study on Forest Laws and Policies in North and Korea. Unification Policy Stud. 2019, 28.

30. Bae, J.S. Afforestation Policy in the 1970s-Establishment of the First 10-Year Forest Conservation and Afforestation Plan and the Clearance Policy for Slash-and-Burn Fields; National Institute of Forest Science: Seoul, Korea, 2007; p. 14.

31. Responsibility Guidance System. 1st-3rd National Forest Master Plans 1973-1997; Korea Forest Service: Daejeon, Korea, 2013; p. 22.

32. Son, Y.H.; Jeong, Y.H. A Study on North Korea's Afforestation Plan. Focused on Agroforestry; Unification Preparation Committee: Seoul, Korea, 2014; pp. 11-14.

33. Forest Restoration Campaign in DPR Korea. Presented by an official of the Ministry of Land and Environmental Protection of DPRK in Switzerland, August 2018.

34. Rodong News Agency. Proud Achievements in the Forest Restoration Battle. Rodong Sinmun, 2 March 2016.

35. Shin, K.S. On the Characteristics of Forest Development Project in our Country. Kim Il-sung Univ. Newsp. 2017, 32.

36. Ministry of Unification North Korean Information. Available online: http://www.nkinfo.unikorea.go.kr (accessed on 8 January 2020).

37. Korean Central News Agency. The DPRK Cabinet Adopted the Decision to Vigorously Advance the Forest Restoration Battle; Korean Central News Agency: Pyongyang, Korea, 2018.

38. Lee, S.K. Studies on North Korean Economic Reforms in the Kim Jong-Un Era; Korea Institute for Industrial Economics \& Trade: Sejong, Korea, 2018; pp. 230-248.

39. Rodong News Agency. Let Us show an Example of the Working Class in the War against Nature. Rodong Sinmun, 15 May 2017.

40. Kim Jong En in North Korea Visits Military Tree Nursery no. 122 and Says, 'valuable Property for the Realization of Afforestation'. Unification News, 16 May 2016.

41. Rodong News Agency. Organizing a Close Monitoring and Crowd Mobilization System. Rodong Sinmun, 7 April 2017.

42. Rodong News Agency. Establishing Nationwide Forest Fire Monitoring Information Service System. Rodong Sinmun, 6 April 2016.

43. Rodong News Agency. Development of National Forest Resource Management Information System in our Style. Rodong Sinmun, 15 July 2016.

44. Park, H.; Lee, J.Y.; Song, M.K. Scientific Activities Responsible for Successful Forest Greening in Korea. Forest Sci. Technol. 2017, 13, 1-8. [CrossRef]

45. Korea Forest Service. The 1st-3rd Basic Forest Plans in 1973-1997; Korea Forest Service: Daejeon, Korea, 2013; pp. 423-434.

46. Rodong News Agency. Forest Development Project Takes a Big Step. Rodong Sinmun, 27 April 2017.

47. Rodong News Agency. Victory Comes before the Battle-in the Works of the Commanders of the Forest Restoration Battle in Yunsan-Gun. Rodong Sinmun, 21 March 2018.

48. Rodong News Agency. Turning into a Business of the Public. Rodong Sinmun, 7 November 2017.

49. Rodong News Agency. We must Plant the Heart of Patriotism First. Rodong Sinmun, 21 June 2017.

50. Rodong News Agency. For Substantial Guidance to the Fertilization Management of Planted Trees. Rodong Sinmun, 7 November 2017.

51. Rodong News Agency. Example Creation and Generalization to Ensure Successful Forest Restoration Battle. 2017. Rodong Sinmun, 21 August 2017.

52. Rodong News Agency. Let Us Push the Socialist Competition Fever to Jump Higher and Faster. Rodong Sinmun, 19 March 2018.

53. Rodong News Agency. Let Us Create a Miracle and Accomplish a Great Achievement in all Areas by Focusing on our Self-Dependence. Rodong Sinmun, 20 January 2018.

54. Rodong News Agency. The Forest Science Department was Established at Kim Il-Sung University. Rodong Sinmun, 27 March 2017.

55. Ministry of Land and Environment Protection; DPRK. DPRK National Agroforestry Strategy and Action Plan. 2015-2024; Ministry of Land and Environment Protection.

56. Yoo, B.I. The Status and Development Directions of Agroforestry; Korea Forest Research Institute: Seoul, Korea, 2000; pp. 24-30. 
57. Kim, I.G. A Few Problems in Turning the Mountains of the Country into Mountains of Gold and Treasure. Kim Il Sung University.

58. Ministry of Land and Environmental Protection(MoLEP) DPR Korea. Ten Years of Sloping Land Management; World Agroforestry Centre ICRAF: Nairobi, Kenya, 2014; pp. 5-6.

59. Lee, S.K. Studies on North Korean Economic Reforms in the Kim Jong-Un Era; Korea Institute for Industrial Economics \& Trade: Sejong, Korea, 2018; pp. 291-298.

60. Xu, J.; Kim, G.J.; Cho, S.R. Development of Agroforestry Technology by Social Participation-Plan for Slope Management in DPRK; Industrial Publishing Company: Pyongyang, Democratic Korea, 2011.

61. Park, S.Y.; Park, K.S.; Park, S.Y. Forest Administrative Organization of North Korea and Characteristics of Forest Work. North Korean Stud. 2008, 4, 88-89.

62. Kim, K.I. A Study on a Few Notable Problems in Forest Restoration Battle in DPRK. Kim Il Sung University. Available online: http://www.ryongnamsan.edu.kp/univ/ko/research/articles/b137fdd1f79d56c7edf3365fea7 520f2/ (accessed on 11 January 2020).

63. Kim Jong Un, First Chairman, Calls for Restoration of Deteriorated Forest in 10 Years. NK Today, 2 March 2015.

64. Korea Forestry Promotion Institute. A Method of Burning a Forest Site and Cultivate Crops to Clear Forests, and then Move to Other Places to Burn Forests and Grow Crops when the Soil Fertility is Exhausted; Forestry Dictionary; Korea Forestry Promotion Institute. Available online: https://www.kofpi.or.kr/ (accessed on 24 January 2020).

65. Bae, J.S.; Lee, K.B.; Ogino, J. Afforestation Policy in the 1970s: Establishment of the First 10-Year Forest Conservation and Afforestation Plan and the Clearance Policy for Slash-and-Burn Field; National Institute of Forest Science: Seoul, Korea, 2007; pp. 29-50.

66. Catholic Peach Broadcasting Radio. We are Expecting Joint Response to Afforestation and Climate Change with North Korea. Open World Today, 16 April 2019. Available online: http://www.cpbc.co.kr/ CMS/radio/program/pro_sub.php?src=\%2Fbbs\%2Fbbs\%2Fboard.php\%3Fbo_table\%3Dopen\&program_fid= 778\&menu_fid=open\&cid=\&yyyymm=(accessed on 20 March 2020).

67. Rodong News Agency. The Important Problem of Forest Protection Project. Rodong Sinmun, 4 June 2019.

68. Rodong News Agency. Desperate Practice Produces Clear Results in the Implementation of Party Policy. Rodong Sinmun, 28 January 2018.

69. Rodong News Agency. Establishing National Forest Protection System in Good Order. Rodong Sinmun, 26 February 2017.

70. Rodong News Agency. The Problem of Planting Trees in spring-A Talk with Workers of the Ministry of Land and Environmental Protection. Rodong Sinmun, 2 March 2012.

71. Supreme People's Assembly. Comrade Choe Ryong-Hae Field Surveyed the Forestry Business in Jeungsan-Gun. Minju Chosun, 23 May 2019.

72. Rodong News Agency. For a New Victory in the Forest Restoration Battle. Rodong Sinmun, 3 January 2018.

73. Decision about transfer of workplace of slash-and-burn field farmers (1949. 11. 29. Cabinet Decision No.167). In North Korean Laws, Agriculture and Fisheries 1297/507, 8.

74. Yu, J.; Park, H.; Lee, S.H.; Kim, K. Review of Slope Criteria and Forestland Restoration Plan in North Korea. J. Korea Soc. Environ. Restor. Technol. 2016, 19, 25. [CrossRef]

75. Ministry of Land and Environmental Protection; DPRK. About Agroforestry. In Yanji International Symposium, International Academic Discussion on Technology and Corporation for Northeast Asia Forest; Ministry of Land and Environmental Protection: Pyongyang, North Korea, 2015.

76. Kim, S.O. Evaluation Method for the Effect of Soil Erosion on Slopes. Geol. Geogr. 2011, 45-46.

77. Baik, S.S.; Jun, S.R. Belt-Type Catch Cropping Method to Reduce Soil Erosion in Sloped Fields. Tech. Innov. 2003, 35-36.

78. Rodong News Agency. Let Us Fight More Forcefully in the Forest Restoration Battle with Passionate Patriotism. 2018. Rodong Sinmun, 29 September 2018.

Publisher's Note: MDPI stays neutral with regard to jurisdictional claims in published maps and institutional affiliations. 